\title{
Research on Countermeasures of Innovation Driven Eco City Construction in Jilin Province
}

\author{
Li-na $X U^{1, a,{ }^{*}}$ \\ ${ }^{1}$ Jilin University of Finance and Economics \\ Changchun City, Jilin Province, China \\ a22011405@qq.com
}

Keywords: Ecological City, Sustainable Development, Innovation Drives

\begin{abstract}
In recent years, our country attaches great importance to the revitalization of northeast old industrial base development, the report of the 18th National Congress of the Communist Party of China clearly put forward the requirement which is to vigorously promote the development of ecological civilization construction, and also for the first time put forward the strategy of innovation driven development. The Party Central Committee has introduced innovation drives into the construction of ecological civilization city, and made effort to construct a new era of socialist ecological civilization. Jilin province is one of China's eco city construction demonstration Provinces. In the process of transformation and development in the city, we should always put the ecological civilization construction in a prominent position. This article focuses on a series of problems such as population density, land use tension, traffic congestion, environmental degradation, frequent pollution and so on in Jilin province. It introduces innovation driving mechanism, through policy innovation, technological innovation and the changes of public awareness and behaviors, and puts forward targeted and feasibility countermeasures, and search the path and countermeasures for the construction of ecological city, to promote the sustainable development of the economy in Jilin province, to promote the construction of happy Jilin province.
\end{abstract}

\section{Introduction}

As our country's "Opinions on Accelerating the Construction of Ecological Civilization" has carried out, relying on the natural resources of our province, Jilin provincial government has put forward the requirement to strengthen the development of the construction of ecological civilization city in Jilin Province, at the same time to achieve steady growth of economy to further strengthen the construction of ecological civilization, realizing the mode of developing environment and economy simultaneously. At the same time, combining with the development of our province's ecological environment, with "Three-year Plan of Ecological Construction" as the overall orientation, Jilin Province introduces development mode of innovation driving mechanism, so as to realize the organic combination of both economic development and ecological construction. 


\section{Experiences and Enlightenments of Foreign Ecological City Construction}

\section{Experiences of Foreign Ecological City Construction}

\section{Eco City Construction in Singapore}

Singapore is known as the world "garden city", aims to promote the harmonious coexistence between man and nature, to break the original people first, unrestricted nature to obtain the development model. In the city planning enacted a special blue and green planning, through the construction of open parks, strengthen the park green corridor connectivity and utilization of coastline advantage strengthening river leisure demand initiatives among let every citizen in work, life and learning are in the garden city, Singapore economic development and finally realize the goal have a beautiful city environment and the sustainable development mode of two-way drive.

\section{Eco City Construction in Australia}

In the 90s of last century, Australia's Whyalla city took the lead in the city's environmental protection plan for a unified combing, integrated implementation. To make the residents for the early realization of the government's commitment to have a good living environment, Whyalla city has passed the energy conservation and alternative energy, sustainable utilization of water resources and wastewater reuse, green building materials and other initiatives to achieve development in the construction of ecological model city.

\section{Enlightenments of Foreign Ecological City Construction}

From the above western ecological city construction, it is not difficult to find out that people and nature are at the same important level. They have recognized the positive role of benign development of ecological environment of the regional economy, at the same time, through the energy saving, emission reduction and development of new energy, they have carried out green initiatives such as waste mode. In addition, greatly influenced by regional differences in the development of our country, Jilin province should also be combined with the high proportion in its own industrial eco city development, the overall characteristics of natural resources are relatively rich, according to China's sustainable development strategy and the supply side structural reform and ecological strategy of three years planning strategy formation model of eco city development with the northeast region the characteristic, and conform to the scientific and technological revolution. We should introduce the concept of scientific and technological innovation, combine economic growth, ecological construction and scientific and technological innovation together, make sky bluer, water greener and air fresher.

\section{The Problems of Ecological City Construction in Jilin Province}

\section{The Total Amount of Forest has Declined Sharply in Eastern Part of Jilin Province}

A sharp decline in timber reserves, by the influence of the original extensive production mode in our province. The consumption of the province's total forest has almost exhausted, apart from the virgin forest, ChangBai Mountain Nature Reserve and other places, is well preserved. At the same time, the ecological capacity of forest vegetation system in soil and water conservation and water conservation also declined drastically .The local environmental protection department is seriously troubled by a series of issues, these are Surface vegetation damaged, water conservation capacity weakened and soil and water conservation capacity decreased These troubles are 
caused by the excessive reclamation. Our province strengthens the intensity of the adjustment of industrial structure and environmental Protection. In recent years, the province has begun to develop large-scale of returning farmland to forests and artificial forest construction work. Although the increase in the total planted forest brought about a temporary increase in forest cover rate, many problems gradually exposed such as single species plantations, weak self-regulation, high Post-maintenance costs, the eco-industrial system is not perfect and the infrastructure construction is backward.

\section{Industrial Structural Pollution is Serious in the Central Region of Jilin Province}

China has entered into a accelerated period featured of mass consumption. Jilin Province is our country's major commodity grain production base; its main industries are the automobile industry and petrochemical industry. The production sector in a dominant position are mainly concentrated in important cities, these production department are medicine, building materials, paper, food processing and high-tech and so on. The proportion of a larger resource-dependent industries formed industrial structural pollution, these industries have high consumption of products, low technological content and poor economic returns. These make the contradictions between Jilin Province environment and the development more prominent that will lead to irrational industrial structure, industrial structural serious pollution.

\section{Three Problems have not been Checked in Northwest of Jilin Province}

The western part of Jilin Province has better ecological capital, but the oil field covers a large area, serious environmental pollution and aggravated land desertification. Since the 80 s of last century there have been three major ecological problems, soil desertification, salinization and grassland degradation. In recent years, although the introduction of related initiatives, but the situation in partial areas are still not optimistic. Grassland degradation caused the problems of the grassland area decreased, grassland quality degradation, grassland ecosystem damaged. These problems hinder the development of animal husbandry in our province. Jilin Province is the country's major commodity grain base. But affected by the lack of farmers lack the awareness of environmental protection and other factors. Our province has been in the grain growing process of the state of cultivation is greater than cultivation. Land nutrient is absorbed by large-scale cultivation year by year, a serious decline in soil fertility. The long run will form a vicious cycle effect.

\section{Countermeasures of Jilin Ecological City Construction by Innovation Drives}

\section{Improve the Ecological Protection System}

With the institutional innovation to guarantee ecological civilization construction, must be based on laws and regulations, must promote reform and innovation mechanism. Using the institution to protect the environment. According to the existing requirements to amend the existing laws and regulations, to strengthen the legal coordination. To establish of Resources and Environment Ecological Red Line System, scientifically define the red line, rationally develop natural resources, protect and repair ecological functions such as cultivated land and rivers. Establishing the property rights of natural resources system and the use of control system; Improving economic policies and promoting market-oriented mechanism, to promote the high utilization of resources and reduce the cost of environmental protection. Taking 
advantages of taxation, finance and other means to promote the use of resources, environmental protection and climate change.

\section{Technological Innovation}

First of all, accelerating the construction of a new system of modern industry in Jilin Province, Strengthen the promotion of technology innovation capacity of heavily polluting industries. Using advanced technology and energy-saving environmental protection technology, to improve resource utilization efficiency and to reduce pollutant emissions. Secondly, develop the ecological services vigorously .According to the characteristics of the first and second industries with a higher proportion ,to establish basic ecological services for the first and second industries. Developing ecological farming mode to strengthen the recycling of waste resources in rural areas and establish a good cycle of ecological farming system. Finally,. To strengthen the ecological responsibility proportion of performance evaluation, implement corporate responsibility and obligations. Actively Constructing the Innovation System of Ecological Science and Technology, named "Government to promote - market pull government, industry, colleges and universities and scientific research institutes linkage".

\section{The Transform of Public Behavior and Awareness}

As a part of the global consciousness of Eco - environmental awareness, which is an important social public awareness. Since reform and opening up, with the rapid economic growth, our country has also paid heavy prices of consuming a lot of resources and environmental pollution. We need to implement the important measures in the future which arouse people's awareness of environmental crisis through environmental education. To stimulate public awareness of environmental protection. Divided the environmental interests from the government monopoly into government, market, the public ternary sharing trend of development through information disclosure. Carrying out civic ecological civilization education, publicizing the important significance of resource conservation and regeneration widely and lasting by using a variety of ways. Make full use of radio, television, newspapers, the Internet and other media, to release popular science knowledge and public service advertisement about resource utilization and protection. To increase the financial tilt of the resources, establish special funds of protecting resources, and give policy support in terms of credit.

\section{Acknowledgement}

This paper is one of the phased objectives of the research which is supported by "the Thirteen Five-year Plan" of social science research projects of the Education Department of Jilin Province and under Grant No. 201672; it is also one of the phased objectives of Jilin University of Finance and Economics university-level project "Jilin Province Eco City Construction Path and Countermeasure Research Based on Innovation Drives" No. 2016q29.

\section{References}

[1] Xiangrong Wang. Theory, Ways and Measures of Eco City Construction -- a Case Study of Shanghai [J]. Journal of Fudan University (NATURAL SCIENCE EDITION), 2001, 40 (4): 349-354. 
[2] Aimin Hou, JinYuan. Successful Experience of Foreign Ecological City Construction [J]. Urban Development Research, 2006, (13): 1-5.

[3] Jiaoguo Ma, Yongchun Yang. The Practice of Foreign Eco City and Its Enlightenment to Chinese [J]. International City Planning, 2006, 21 (2): 71-74.

[4] Zhenhuan Yao. Suggestions on Promoting Eco City Construction in Jilin Province [J]. Intelligence, 2012 (13): 265.

[5] Bo Gao. Scientific and Technological Innovation Driven Strategy [J]. Water Ecological Civilization Construction of Water Conservancy in China, 2013 (15): 6-8. 